\title{
SELECTED ENTREPRENEURSHIP SUPPORT FACTORS INCREASING WOMEN'S SAFETY AND WORK COMFORT
}

doi: $\quad 10.2478 /$ czoto-2019-0015

Date of submission of the article to the Editor: 07/11/2018

Date of acceptance of the article by the Editor: 05/01/2019

Małgorzata Rembiasz ${ }^{1}$ - orcid id: 0000-0001-6605-4499

Paulina Siemieniak ${ }^{1}$ - orcid id: 0000-0002-0910-3394

${ }^{1}$ Poznań University of Technology, Poland, malgorzata.rembiasz@put.poznan.pl

\begin{abstract}
Over the last twenty years a growing number of researchers have been interested in female entrepreneurship. Every third business venture in the world is run by a woman. Brief Women business owners face substantial risks and uncertainty. Women tend to take entrepreneurial risks if provided with various forms of support that increase their sense of psychological safety and work comfort. The below study findings identify the most useful support methods. The subject of the survey was to determine on a scale of five the usefulness of individual forms of business support. Respondents answered, how useful is listed form of business support. Support should be tailored to the demographic characteristics of women. In depending on the stage of life and life situation women need different support. The barriers to women entrepreneurship result not as much from difficulties in obtaining funding but rather from the frustration resulting from unfulfilled social needs. Access to support from the state, social organizations and family members increases the sense of psychological safety and work comfort in women, leading to a greater propensity to take risks and start and run businesses.
\end{abstract}

Keywords: women's safety and work comfort, entrepreneurship support factors, women entrepreneurs, women's labor.

\section{INTRODUCTION}

As a general rule, business owners tend to feel less secure than holders of permanent jobs. Entrepreneurs are constantly confronted with uncertainty as their markets and competition change. Particularly vulnerable to such factors are women entrepreneurs who devote a substantial portion of their time to motherhood. At times, the need to generate a steady income stands in contrast to the need to organize one's time flexibly. This is of particular importance for single mothers who are often the only bread-winners in the family (Rembiasz, 2016).

Every entrepreneur lives in conditions of constant uncertainty, i.e. mismatches between necessary and available knowledge to make a decision. Faced with perpetual uncertainty, individuals need safety to achieve a sense of control over themselves and their environments. Specific circumstances, emotions, timing and cultural factors all contribute to the sense of safety (Bańka, 2002). 
Control is therefore one of the factors determining the well-being of the individual. In the entrepreneur's work, it involves with flexibility in determining tasks and the manner and time of their implementation (Siemieniak and Rembiasz, 2018). To achieve a sense of control, people are constantly forced to assess threats and deal with lacking knowledge and clarity (Sadłowska - Wrzesińska et al., 2016). The sense of safety affects subjective assessments of risk acceptability (Klamut, 2012). In running their own business, sources of risk should be recognized at every level of management and, above all, controlled. To this end, actions must be taken to minimize the likelihood of these risks occurring. It is also necessary to support the increase in the security of processes that occur in the enterprise during its everyday operation. This will ensure, in the long-term perspective, the achievement or increase of profit, or at least it will not lead to a loss. (Stańczak, 2014). The experience receiving support increases the sense of safety. Therefore, and quite expectedly, once the need for safety and greater risk tolerance has been satisfied, women become more prone to engage in business and help fuel the overall economic growth and secure prosperity for all.

The above theory has been applied to formulate the assumption that women tend to take entrepreneurial risks if provided with various forms of support that increase their sense of psychological safety and work comfort.

\section{METHODOLOGY OF RESEARCH}

The main factors that enhance the sense of psychological safety in women entrepreneurs is the ability to share household chores, access to a social support network, the availability of institutions offering flexible forms of child care, access to information on running a business from family members and various forms of financial support. In the study in question, such factors were correlated with the demographic characteristics of women linked to their roles as mothers, the number of children they have, their marital status, whether the enterprise is run as a sole or an additional source of income and whether the women are the sole owner or a co-owner of their business.

The surveys were conducted covering 384 respondents residing in the Region of Wielkopolska. In the study was used authored paper questionnaire and online survey. The subject of the survey was to determine on a scale of five the usefulness of individual forms of business support. Respondents answered, how useful is listed form of business support. The respondents - women entrepreneurs - characterized by the following features: $82 \%$ of them had children, about $40 \%$ were mothers of two children, and $28 \%$ had one child, $71 \%$ were married, the largest group were women working in trade (around 37,5\%). Companies run by women were small size: $67.7 \%$ of respondents were self-employment, micro-enterprise was $27,1 \%$. Conducted enterprise was the only place of work for $85 \%$ respondents, and the additional workplace for $15 \%$ of them. $30 \%$ of women led the company less than one year, one year to ten years existed $40 \%$ of companies, and more than 10 years- $30 \%$ of enterprises. The respondents offered specific conclusions on the usefulness of various forms of support designed to improve the sense of safety associated with running a business.(Siemieniak and Rembiasz, 2017). 


\section{RESULTS}

The forms of support identified as being the most effective in enhancing the sense of safety and work comfort in individual groups of women entrepreneurs are summarized in Table 1. They have been identified as useful or very useful in supporting women entrepreneurs.

Table 1

Selected entrepreneurship support factors increasing women's safety and work comfort.

\begin{tabular}{|c|c|}
\hline Support factor & $\begin{array}{l}\text { Women for whom as given factor increasing } \\
\text { women's safety and work comfort }\end{array}$ \\
\hline Sharing household chores & $\begin{array}{l}- \text { aged } 18 \text { to } 39, \\
\text { - } \text { childless or with two children, } \\
\text { - } \text { married, } \\
\text { - } \text { business used as an additional source of } \\
\text { income }\end{array}$ \\
\hline Social support network & $\begin{array}{l}\text { - aged } 18 \text { to } 29 \\
\text { - childless, } \\
\text { - in an informal relationship. }\end{array}$ \\
\hline $\begin{array}{l}\text { Information on running a business } \\
\text { received from family members and } \\
\text { acquaintances }\end{array}$ & $\begin{array}{ll}- & \text { aged } 18 \text { to } 39, \\
\text { - } & \text { childless, } \\
\text { - } & \text { single or in an informal relationship, } \\
\text { - } & \text { business used as an additional source of } \\
& \text { income, } \\
- & \text { in business for less than a year or in the } \\
& \text { process of starting a business }\end{array}$ \\
\hline Child-care institutions & $\begin{array}{l}- \text { aged } 18 \text { to } 39 \\
\text { - } \text { living in rural areas }\end{array}$ \\
\hline Financial aid: subsidies and tax breaks & $\begin{array}{l}\text { - } \quad \text { aged } 18 \text { to } 39, \\
\text { - } \quad \text { with } 3 \text { or more children, } \\
\text { - } \quad \text { married or in an informal relationship, } \\
\text { - } \quad \text { in business for less than a year or in the } \\
\quad \text { process of starting a business }\end{array}$ \\
\hline
\end{tabular}

The study has found that, as perceived by the women entrepreneurs, the foremost factors that increase psychological safety at work are having a variety of social network contacts. Research has shown that support should be tailored to the demographic characteristics of women. In depending on the stage of life and life situation women need different support. Women highly value the assistance of people with whom they have close relationships. This is especially important because, as the results of other studies show, that the majority of respondents felt that women experience a greater conflict than men between their professional and parental roles (Rembiasz and Siemieniak, 2018).

In the case of women of childbearing age, the most important support factors in running a business are: the ability to share household responsibilities with a partner, acquiring information from friends and using social support networks. For the comfort and safety of work women living in rural areas need easily accessible institutions caring for children. In Poland kindergartens and nurseries are difficult to access in rural areas. Even in big cities, institutional child care is open during hours that are not always suited to mothers' working hours. 
Moreover low evaluated are the forms of enterprise development, which result from contact with strangers, e.g. with representatives of business environment institutions and centers of advisory (Siemieniak and Rembiasz, 2017).

\section{DISCUSSION}

An analysis of the available research findings suggests that women-run enterprises are less effective and less growth-oriented than those operated by men. This may result from women's greater risk aversion compared to men (Siemieniak and Łuczka, 2016) and a lesser sense of psychological safety. The relevant literature shows that women tend to be less risk-prone and more anxious about incurring a loss (Grilo et al., 2007).

Other studies reveal that women tend to be more meticulous about risk assessment. They are more willing than men to rely on external advisors to resolve business crises (Robb et al., 2014). Moreover, women, particularly in Poland, are less likely to assume financial risks and therefore more reluctant to use external financing (Małecka and Łuczka, 2016).

Different results are provided by PARP (The Polish Agency for Enterprise Development) research, which shows that there are no significant differences between women and men in risk-taking attitude. The obtained results do not confirm the popular thesis that women's fear of unstable incomes from their own business is the reason for the relatively low share of women among entrepreneurs. On the other hand, the researchers note differences between entrepreneurs and nonentrepreneurs. Entrepreneurs more often declare and actually take risks (PARP 2011). Therefore, not sex, but the entrepreneurial attitude probably determines the attitude to risk.

Note also that women with children are the most likely to need to feel secure in their employment / business pursuits. They should therefore be offered access to various forms of support with that regard. This is of particular importance for single mothers. Women being heads of single-parent families face many difficulties in remaining in the labour market, since they are less available having to care for their children and to do a multitude of household chores. This social group, however, seems capable of being active and entrepreneurial despite existing constraints. For both economic and social reasons, the government should be concerned withdeveloping entrepreneurial attitudes in that group of women and launch ingmechanisms for making use of such attitudes in practice (Rembiasz, 2016).

In addition to the risk and uncertainty experienced by all entrepreneurs, women experience additional difficulties resulting from the traditional division of household duties (Siemieniak and Rembiasz, 2018). A significant difference in barriers to doing business between men and women lies in conditions of family life and caretaking responsibilities for young children. Women more often than men point to limited access to institutional care of children (PARP, 2011).

The majority of entrepreneurship support factors increasing women's safety and work comfort have a positive effect on work life balance. Access to support is also associated with corporate social responsibility (Górny, 2017). 


\section{CONCLUSION}

The perception of risks being associated with running one's own business diminishes as business owners acquire more information, get in contact with other entrepreneurs, share household chores and gain access to subsidies and tax relief. The findings show also that, contrary to popular belief, the barriers to women entrepreneurship result not as much from difficulties in obtaining funding but rather from the frustration resulting from unfulfilled social needs.

Access to support from the state, social organizations and family members increases the sense of psychological safety and work comfort in women, leading to a greater propensity to take risks and start and run businesses. Note that increases in the sense of safety reported by women entrepreneurs result predominantly from social factors associated with supportive relationships with other people.

From the perspective of the development of the research into the entrepreneurship support factors increasing women's safety and work comfort, the issue concerning the formation of entrepreneurial attitudes of young women, especially those educated, seems to be important. It is therefore worth to develop research on the students' intentions to run a business (Łuczka and Rembiasz, 2016).

For economic and social reasons, the state should formulate a policy that will foster entrepreneurship. Specific mechanisms should be established that help attain this goal, targeted especially at women.

\section{REFERENCES}

Bańka A., 2002. Społeczna psychologia środowiskowa, Warszawa. Wydawnictwo Naukowe Scholar.

Górny A., 2017. Safety-at-work competences as a driver of corporate social responsibility. 8th International Conference on Manufacturing Science and Education, MSE 2017, MATEC Web of Conferences, 121, 11009.

Grilo, I., Thuric, R., Verheul, I., Van Der Zwan P., 2008. Climbing the Entrepreneurial Ladder: The Role of Gender. Retrieved from http://ssrn.com/abstract=1088219

Klamut R., 2012. Bezpieczeństwo jako pojęcie psychologiczne. Zeszyty Naukowe Politechniki Rzeszowskiej, 289, Ekonomia i Nauki Humanistyczne,19 (4), 41-51, DOI: 10.7862/rz.2012.einh.26

Łuczka, T. i Rembiasz, M., 2016. Badanie postaw przedsiębiorczych studentów wybrane aspekty teoretyczne i empiryczne. Horyzonty Wychowania, 15 (34), 2747. DOI: 10.17399/HW.2016.153402

Małecka, J., Łuczka, T., 2016. The Structure of Venture Capital Raising by Companies in Poland and Central and Eastern Europe: Selected Aspects. IMECS 2016, 418-431.

PARP, 2011. Women Entrepreneurship in Poland, Warsaw.

Rembiasz, M., 2016. Entrepreneurship of single mothers: selected economic and social aspects. Zeszyty Naukowe PP, Organizacja i Zarządzanie, 68, 167-179.

Rembiasz, M., Siemieniak, P., 2018. Kształtowanie postaw przedsiębiorczych studentek $w$ kontekście konfliktu roli rodzicielskiej i zawodowej. Horyzonty Wychowania, 17(43), 197-207. DOI: 10.17399/HW.2018.174317

Sadłowska - Wrzesińska, J., Górny, A., Mościcka-Teske, A., 2016. The outcomes of shift working in the context of psychosocial functioning - sex aspects. P. Arezes, 
et al. (eds.), Occupational Safety and Hygiene IV: 197-201, London: CRC Press, Taylor and Francis Group.

Siemieniak P., Rembiasz M., 2018. Work life balance $w$ życiu kobiet- obecnych $i$ potencjalnych przedsiębiorców. Zeszyty Naukowe Politechniki Poznańskiej, Organizacja i Zarządzanie, 76, 229-242, DOI: 10.21008/.0239-9415.2017.074.01

Siemieniak P., Rembiasz M., 2017. The need for the psychological safety in women entrepreneurs. SHO 2017 International Symposium on Occupational Safety and Hygiene, red. Arezes, P. Baptista J.S., Barroso M.P., Carneiro, P., Costa N., Melo, R., Miguel , A.S., Perestrelo, G., Wyd. Portuguese Society of Occupational Safety and Hygiene, 102-103.

Siemieniak, P., Łuczka, T., 2016. Przedsiębiorczość kobiet. Wybrane aspekty ekonomiczne i psychokulturowe. Poznań, Wydawnictwo Politechniki Poznańskiej.

Stańczak A., 2014. Ryzyka prowadzenie działalności gospodarczej w Polsce ze szczególnym uwzględnieniem sektora małych i średnich przedsiębiorstw. ZNUV, 35, 82-98. 